\title{
An Investigation of In Situ Hydrothermal Oxidative Destruction of NDMA
}

R. N. Leif, K. G. Knauss, R. D. Aines

February 25, 1999

U.S. Department of Energy

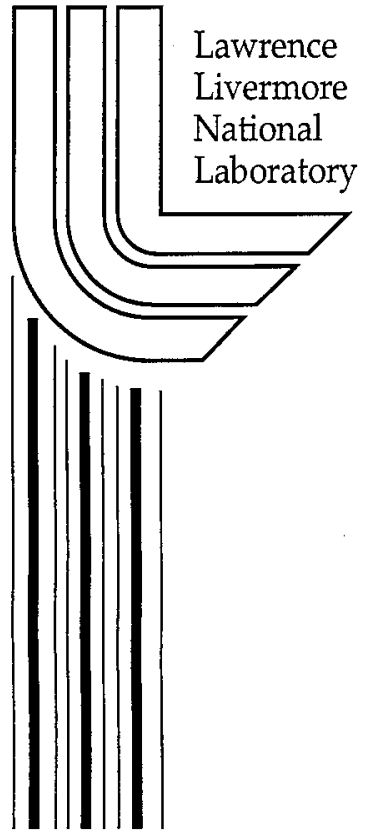




\section{DISCLAIMER}

This document was prepared as an account of work sponsored by an agency of the United States Government. Neither the United States Government nor the University of California nor any of their employees, makes any warranty, express or implied, or assumes any legal liability or responsibility for the accuracy, completeness, or usefulness of any information, apparatus, product, or process disclosed, or represents that its use would not infringe privately owned rights. Reference herein to any specific commercial product, process, or service by trade name, trademark, manufacturer, or otherwise, does not necessarily constitute or imply its endorsement, recommendation, or favoring by the United States Government or the University of California. The views and opinions of authors expressed herein do not necessarily state or reflect those of the United States Government or the University of California, and shall not be used for advertising or product endorsement purposes.

This work was performed under the auspices of the U. S. Department of Energy by the University of California, Lawrence Livermore National Laboratory under Contract No. W-7405-Eng-48.

This report has been reproduced directly from the best available copy.

Available to DOE and DOE contractors from the Office of Scientific and Technical Information

P.O. Box 62, Oak Ridge, TN 37831

Prices available from (423) 576-8401

http://apollo.osti.gov/bridge/

Available to the public from the National Technical Information Service

U.S. Department of Commerce 5285 Port Royal Rd., Springfield, VA 22161

http://www.ntis.gov/

OR

Lawrence Livermore National Laboratory Technical Information Department's Digital Library

http://www.llnl.gov/tid/Library.html 
Final Report to NASA - White Sands Test Facility

An Investigation of In Situ Hydrothermal Oxidative Destruction of NDMA

\section{Principle Investigators :}

Roald N. Leif, Kevin G. Knauss and Roger D. Aines

Geosciences and Environmental Technology

Lawrence Livermore National Laboratory

Livermore, CA 94550 


\section{TABLE OF CONTENTS}

$\begin{array}{lc}\text { COVER PAGE } & 1\end{array}$

$\begin{array}{lr}\text { TABLE OF CONTENTS } & 2\end{array}$

$\begin{array}{ll}\text { ABSTRACT } & 3\end{array}$

$\begin{array}{ll}\text { INTRODUCTION } & 4\end{array}$

$\begin{array}{lc}\text { METHODS } & 5\end{array}$

EXPERIMENTAL METHODS

ANALYTICAL METHODS

$\begin{array}{lr}\text { RESULTS } & 7\end{array}$

$\begin{array}{ll}\text { NDMA05 }\left(180^{\circ} \mathrm{C}\right) & 7\end{array}$

$\begin{array}{ll}\text { NDMA04 }\left(190^{\circ} \mathrm{C}\right) & 7\end{array}$

$\begin{array}{ll}\text { NDMA06 }\left(200^{\circ} \mathrm{C}\right) & 8\end{array}$

NDMA08 $\left(210^{\circ} \mathrm{C}\right) \quad 8$

$\begin{array}{ll}\text { NDMA07 }\left(220^{\circ} \mathrm{C}\right) & 8\end{array}$

$\begin{array}{ll}\text { DISCUSSION } & 14\end{array}$

DETERMINATION OF HPO RATE CONSTANTS 14

THE ARRHENIUS EQUATION FOR THE HPO OF NDMA 17

$\begin{array}{ll}\text { SUMMARY } & 20\end{array}$

$\begin{array}{ll}\text { APPENDIX } & 21\end{array}$ 


\begin{abstract}
Rate constants for the aqueous oxidation of N-nitrosodimethylamine (NDMA) have been measured in aqueous phosphate-buffered solutions using Dickson-type vessels. The initial NDMA concentrations ranged from 2.5 to $2.8 \mathrm{ppm}$ and reaction temperatures varied from $180^{\circ} \mathrm{C}$ to $220^{\circ} \mathrm{C}$. Quantitation of NDMA was performed by gas chromatography-mass spectrometry (GC-MS) using selected ion monitoring (SIM). NDMA loss with concomitant production of nitrite and nitrate confirmed that mineralization of NDMA occurred, and no intermediates amenable to GCMS were formed during the oxidation experiments. First order reaction rate constants for the loss of NDMA were determined by the integral method and the results are as follows : $\mathrm{k}_{1}=5.21 \times 10^{-7}$ $\mathrm{s}^{-1}$ at $180^{\circ} \mathrm{C}, \mathrm{k}_{1}=1.14 \times 10^{-6} \mathrm{~s}^{-1}$ at $190^{\circ} \mathrm{C}, \mathrm{k}_{1}=2.05 \times 10^{-6} \mathrm{~s}^{-1}$ at $200^{\circ} \mathrm{C}, \mathrm{k}_{1}=4.53 \times 10^{-6} \mathrm{~s}^{-1}$ at $210^{\circ} \mathrm{C}$ and $\mathrm{k}_{1}=8.81 \times 10^{-6} \mathrm{~s}^{-1}$ at $220^{\circ} \mathrm{C}$. The Arrhenius equation for this data is listed below :

$$
\ln (\mathrm{k})=20.21-15716(1 / \mathrm{T})
$$
\end{abstract}

The activation energy for this process is calculated to be $130.7 \pm 3.5 \mathrm{~kJ} / \mathrm{mole}$. Extrapolating to a temperature of $125^{\circ} \mathrm{C}$, a reasonable process temperature in the subsurface of WSTF, results in a calculated first order rate constant of $4.30 \times 10^{-9} \mathrm{~s}^{-1}$ and a half-life of 1870 days. 


\section{INTRODUCTION}

Five screening experiments on the aqueous phase oxidation of NDMA were performed using Dickson-type flexible gold bag rocking autoclaves. The overall objective of this project was to determine if hydrous pyrolysis/oxidation (HPO) is a feasible method for destroying NDMA under acceptable time and temperature conditions. A suitable analytical method for the measurement of NDMA in small water samples by combining a extraction/concentration step of solid phase extraction (SPE) with GC-MS analysis using selected ion monitoring (SIM). For these five experiments all of the surrogate recoveries fell in a range of 90 to 106\% recovery and therefore no data was rejected due to poor extraction efficiency.

Total inorganic nitrogen ( measured as nitrite and nitrate) and total inorganic carbon (measured as carbon dioxide) were monitored throughout the reaction. On the basis of the preliminary test results, we have performed these experiments in the temperature range of $180^{\circ} \mathrm{C}$ to $220^{\circ} \mathrm{C}$ and constructed an Arrhenius plot to determine rate constants at temperatures outside of the range of experimental temperatures. 


\section{METHODS}

\section{EXPERIMENTAL METHODS}

The laboratory HPO experiments were performed in Dickson-type flexible gold bag rocking autoclaves. These reactors are designed for periodic sampling of the reaction fluids throughout the course of an experiment without disturbing temperature or pressure. The vessel pressure is held constant by adding or removing distilled water from around the sealed gold bag using a constant pressure HPLC syringe pump. In these experiments the pressure was set at $500 \mathrm{psi}$, a pressure sufficient to keep the system as a single phase. The $\mathrm{pH}$ was fixed at $\mathrm{pH}=7$ using a dilute inorganic phosphate buffer $\left(\mathrm{KH}_{2} \mathrm{PO}_{4}\right.$ and $\left.\mathrm{K}_{2} \mathrm{HPO}_{4}\right)$ with an ionic strength of $0.033 \mathrm{M}$ and total $\left[\mathrm{PO}_{4}^{3-}\right]=0.0155 \mathrm{~m}$. For each experiment, a measured amount of aerated buffer solution was transferred to the gold bag. An aliquot of the neat NDMA was transferred to each buffer solution using a $1 \mathrm{uL}$ syringe. The vessel was then sealed and sampled prior to heating.

\section{ANALYTICAL METHODS}

Samples of the vessel fluids were taken through titanium valves and directly into glass gas-tight syringes equipped with gas-tight closures. The sampled fluids and dissolved gases were analyzed using a variety of analytical techniques described below. Quantitation of NDMA involved an extraction step prior to analysis by GC-MS. In this procedure, the NDMA in the water sample was extracted using a solid phase extraction (SPE) cartridge packed with $200 \mathrm{mg}$ of ENV+ (International Sorbent Technology), a highly cross-linked styrene-divinylbenzene resin. Each SPE cartridge was conditioned prior to sample extraction by flushing the cartridge with $5 \mathrm{~mL}$ of dichloromethane, $5 \mathrm{~mL}$ of methanol, and $5 \mathrm{~mL}$ of distilled water. Sample sizes ranged from 3.5 to 8 $\mathrm{mL}$. Each sample was transferred to an SPE cartridge and 5 ug of the surrogate $\mathrm{N}$ -

nitrosodiethylamine (NDEA), a compound with similar physical and chemical properties, was added prior to extraction. Each cartridge was air dried and analytes eluted with $5 \mathrm{~mL}$ of dichloromethane. 
Eluent volumes were adjusted to $1 \mathrm{~mL}$ using a stream of dry nitrogen gas after a $5 \mathrm{ug}$ aliquot of internal standard (naphthalene- $\mathrm{d}_{8}$ ) was added to each extract.

Gas chromatography-mass spectrometry (GC-MS) analyses were performed using a Hewlett Packard 6890 gas chromatograph equipped with a $60 \mathrm{~m}$ x $0.32 \mathrm{~mm}$ i.d. Rtx 502.2 (Restek) capillary column $(0.32 \mu \mathrm{m}$ film thickness) coupled to a Hewlett Packard 6890 Series Mass Selective Detector (MSD) operated in electron impact mode (70eV) using selected ion monitoring (m/z 74 for NDMA, m/z 102 for NDEA and m/z 136 for naphthalene- $\mathrm{d}_{8}$ ). The GC oven temperature was programmed as follows : isothermal for $2 \mathrm{~min}$. at $35^{\circ} \mathrm{C}$, ramped at $8^{\circ} \mathrm{C} / \mathrm{min}$. to $260^{\circ} \mathrm{C}$, and held isothermal for $5 \mathrm{~min}$. The injector temperature was set at $250^{\circ} \mathrm{C}$ and helium used as the carrier gas. The GC-MS data was processed using Hewlett Packard Chemstation software. Internal standard method, using a relative response factor, was used for compound quantitation. This method was found to be a suitable analytical method for measuring the aqueous concentrations of NDMA at concentrations ranging from approximately $0.10 \mathrm{ug} / \mathrm{g}$ to $3.0 \mathrm{ug} / \mathrm{g}$.

The aqueous concentrations of nitrite and nitrate were measured using a Hewlett Packard Model 1090 HPLC using a Dionex IonPac AS4A-SC column with a Dionex ASRS-II supressor unit coupled to a Waters 431 conductivity detector.

Total inorganic carbon was measured using an OI Model 524 carbon analyzer. A weighed sample was injected into a vessel containing a $25 \%$ phosphoric acid solution purged with nitrogen gas. Dissolved inorganic carbon is converted to $\mathrm{CO}_{2}$ and swept into a non-dispersive infrared detector where the total inorganic carbon, in the form of carbon dioxide, is measured.

Dissolved oxygen in the solutions was measured using a Microelectrodes Inc. model OM-4 oxygen membrane sensor. The samples were allowed to come to room temperature before measuring dissolved oxygen to decrease the amount of drift due to temperature differences. 


\section{RESULTS}

The following sections detail the results of the five NDMA experiments. The primary objectives of these experiments were to measure NDMA reaction kinetics under HPO conditions, identify oxidation products, and determine the temperature dependence of the rate constants from the Arrhenius equation. Five experiments were set up with the reaction temperatures ranging from $180^{\circ} \mathrm{C}$ to $220^{\circ} \mathrm{C}$. NDMA and the NDMA breakdown products (i.e. nitrite and nitrate) were measured. The nitrogen balance numbers reported in this section were determined by calculating the percentage of nitrogen in reacted NDMA that was recovered as inorganic nitrogen (nitrite and nitrate). No intermediates in the SPE extracts were detected by GC-MS when selected samples were analyzed under full scan mode (m/z 35 to $\mathrm{m} / \mathrm{z} 350)$.

\section{NDMA05 - $180^{\circ} \mathrm{C}$}

The complete set of data for experiment NDMA05 is summarized in Table 1. The second column in Table 1 is the elapsed time calculated by defining $t=0$ as the time at which the vessel heater was turned on and the third column is an adjusted time scale used to calculated kinetics at reaction temperature. For example, sample NDMA05-0 was sampled prior to heating and therefore has a calculated elapsed time of -0.99 days. This experiment was run for 70 days at $180^{\circ} \mathrm{C}$. During this time $96 \%$ of the NDMA was converted. The NDMA and inorganic nitrogen data for this experiment are plotted in Fig. 1. The ratio of nitrite to nitrate production was approximately 6.7 and $90 \%$ of the nitrogen present in NDMA was recovered as nitrite and nitrate.

\section{NDMA04 $-190^{\circ} \mathrm{C}$}

The complete set of data for experiment NDMA04 is summarized in Table 1. This experiment was run for 46 days at $190^{\circ} \mathrm{C}$. During this time $99 \%$ of the NDMA was converted. The NDMA and inorganic nitrogen data for this experiment are plotted in Fig. 2. The ratio of nitrite to nitrate production was approximately 6.8 and $93 \%$ of the nitrogen present in NDMA was recovered as 
nitrite and nitrate. The amount of NDMA in sample NDMA04-46 fell below the low point of the GC-MS calibration curve for NDMA. Although the data is reported, it was not used in the kinetics calculations.

\section{NDMA06 $-200^{\circ} \mathrm{C}$}

The complete set of data for experiment NDMA06 is summarized in Table 1. This experiment was run for 21 days at $200^{\circ} \mathrm{C}$. During this time $98 \%$ of the NDMA was converted. The NDMA and inorganic nitrogen data for this experiment are plotted in Fig. 3. The ratio of nitrite to nitrate production was approximately 6.4 and $100 \%$ of the nitrogen present in NDMA was recovered as nitrite and nitrate. The last two sampling events (NDMA06-18 and -21) had NDMA amounts below the calibration curve and therefore the data was rejected prior to the kinetics calculations.

\section{NDMA08 $-210^{\circ} \mathrm{C}$}

The complete set of data for experiment NDMA08 is summarized in Table 1. This experiment was run for 11 days at $210^{\circ} \mathrm{C}$. During this time $99 \%$ of the NDMA was converted. The NDMA and inorganic nitrogen data for this experiment are plotted in Fig. 4. The ratio of nitrite to nitrate production was approximately 6.0 and $104 \%$ of the nitrogen present in NDMA was recovered as nitrite and nitrate. The NDMA data of sample NDMA08-11 was rejected prior to the kinetics calculations because the measured amount fell below the calibration curve.

\section{NDMA07 $-220^{\circ} \mathrm{C}$}

The complete set of data for experiment NDMA07 is summarized in Table 1. This experiment was run for 8 days at $220^{\circ} \mathrm{C}$ and $99 \%$ of the NDMA was converted. The NDMA and inorganic nitrogen data for this experiment are plotted in Fig. 5. The ratio of nitrite to nitrate was approximately 6.7 and $105 \%$ of the nitrogen present in NDMA was recovered as nitrite and nitrate. The NDMA data from samples NDMA07-5, -7 and -8 were not used in kinetics calculations because the measured amount fell below the calibration curve. 


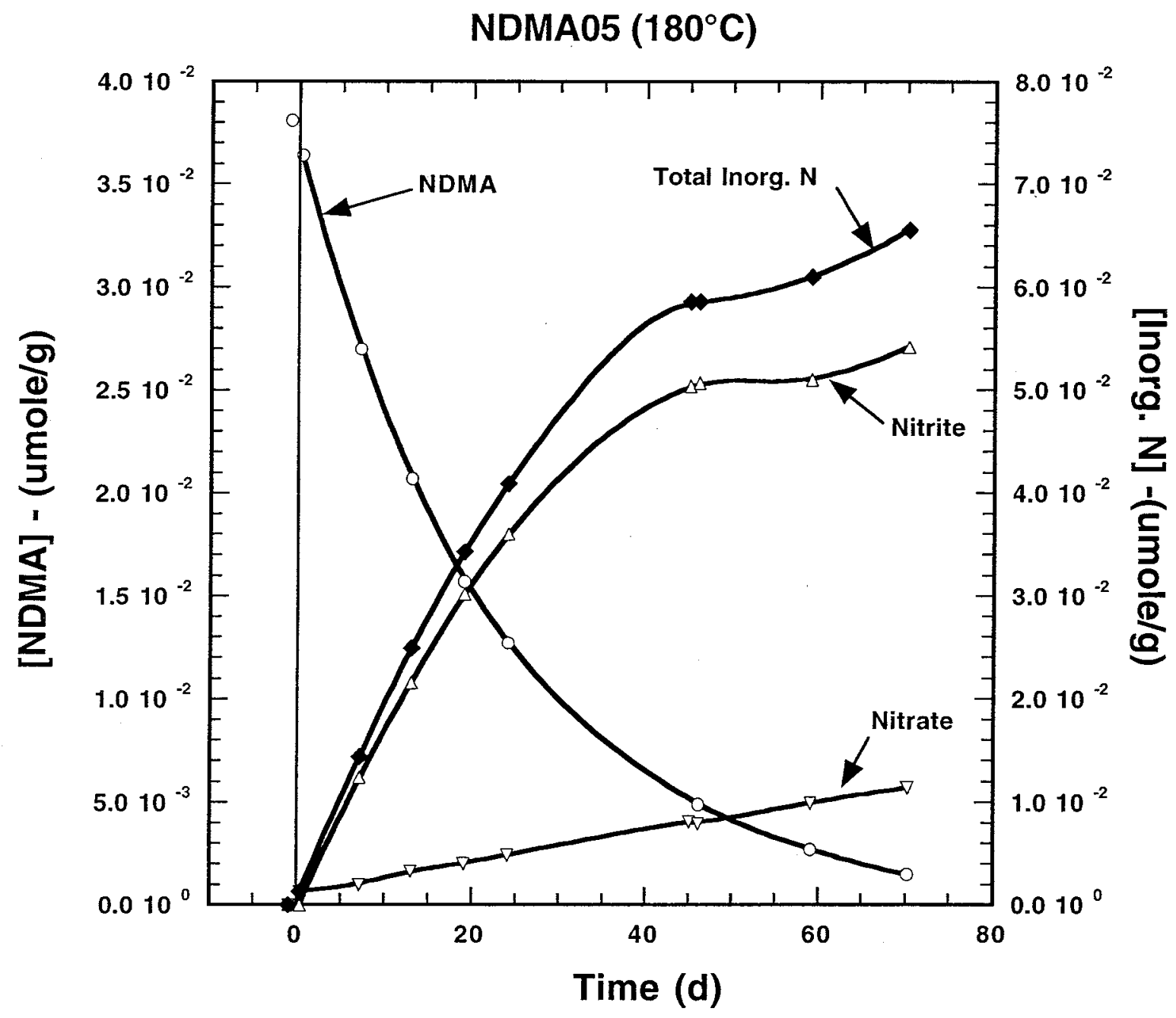

Figure 1. Concentration of NDMA, nitrite and nitrate vs. time for the phosphate-buffered $(\mathrm{pH}=7)$ NDMA experiment run at $180^{\circ} \mathrm{C}$ and $10 \mathrm{ppm}$ dissolved $\mathrm{O}_{2}$. Vertical line at $\mathrm{t}=0$ represents the time when the reaction heater was turned on. 


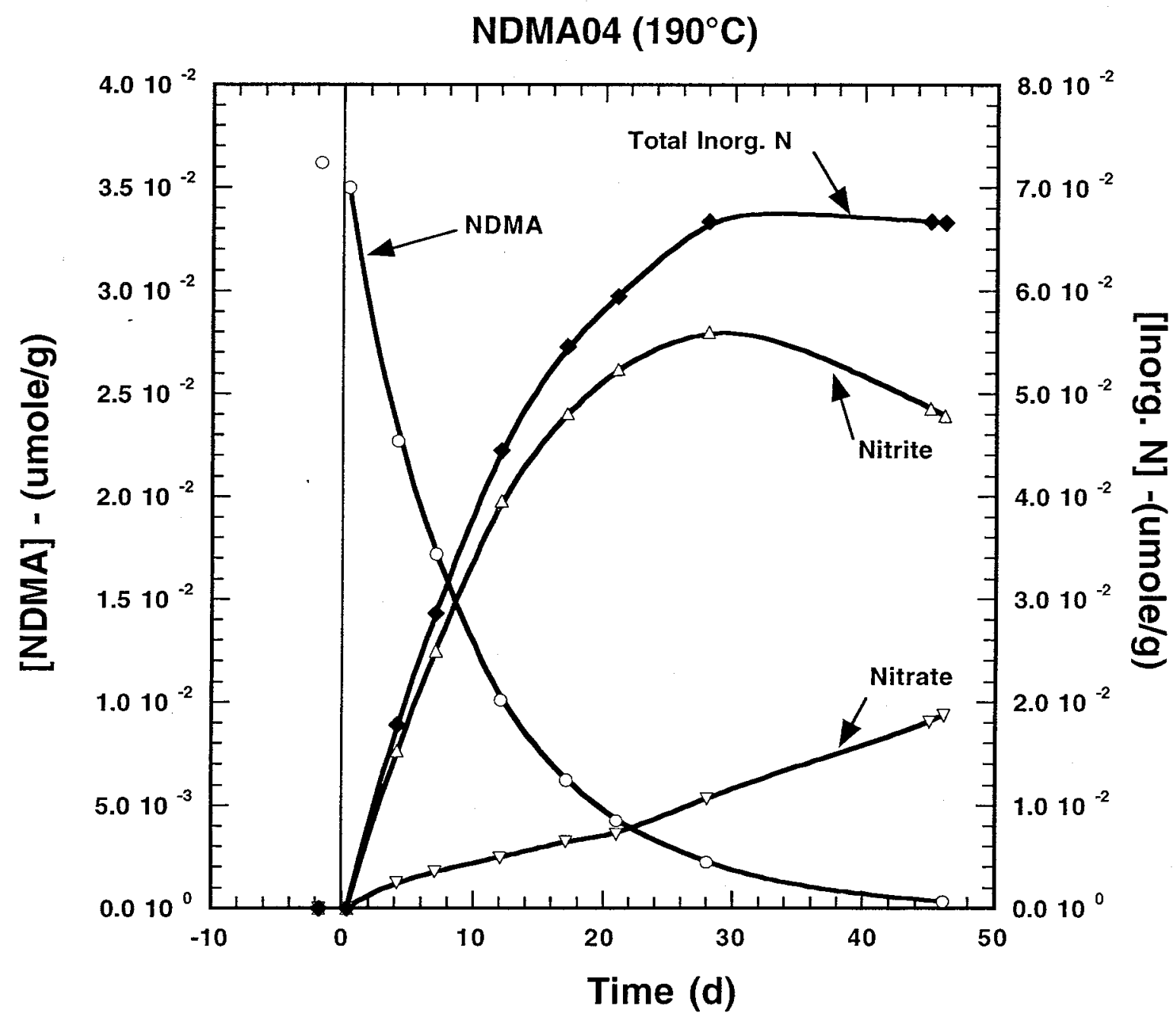

Figure 2. Concentration of NDMA, nitrite and nitrate vs. time for the phosphate-buffered $(\mathrm{pH}=7)$ NDMA experiment run at $190^{\circ} \mathrm{C}$ and $11 \mathrm{ppm}$ dissolved $\mathrm{O}_{2}$. Vertical line at $\mathrm{t}=0$ represents the time when the reaction heater was turned on. 


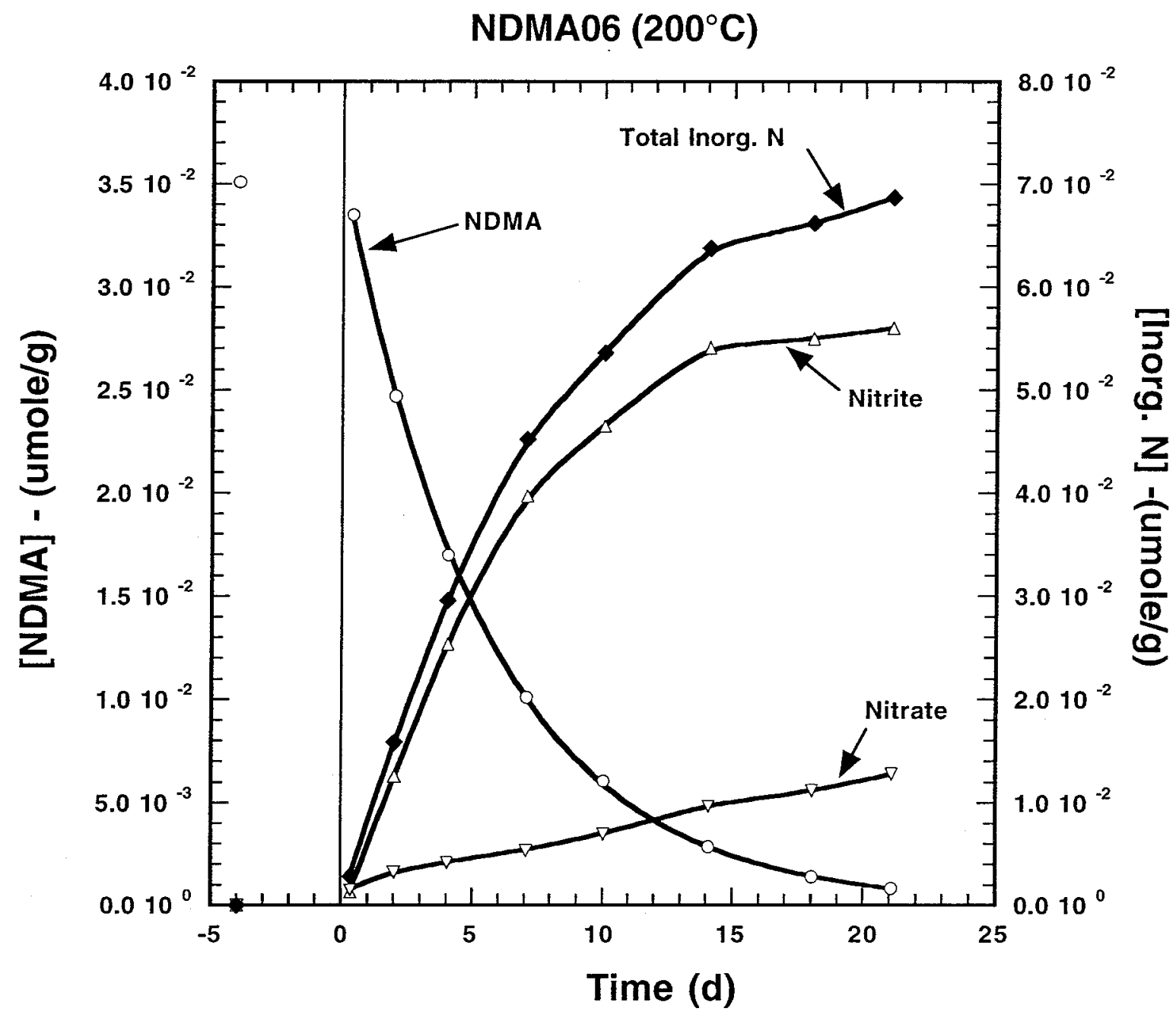

Figure 3. Concentration of NDMA, nitrite and nitrate vs. time for the phosphate-buffered $(\mathrm{pH}=7)$ NDMA experiment run at $200^{\circ} \mathrm{C}$ and $11 \mathrm{ppm}$ dissolved $\mathrm{O}_{2}$. Vertical line at $\mathrm{t}=0$ represents the time when the reaction heater was turned on. 


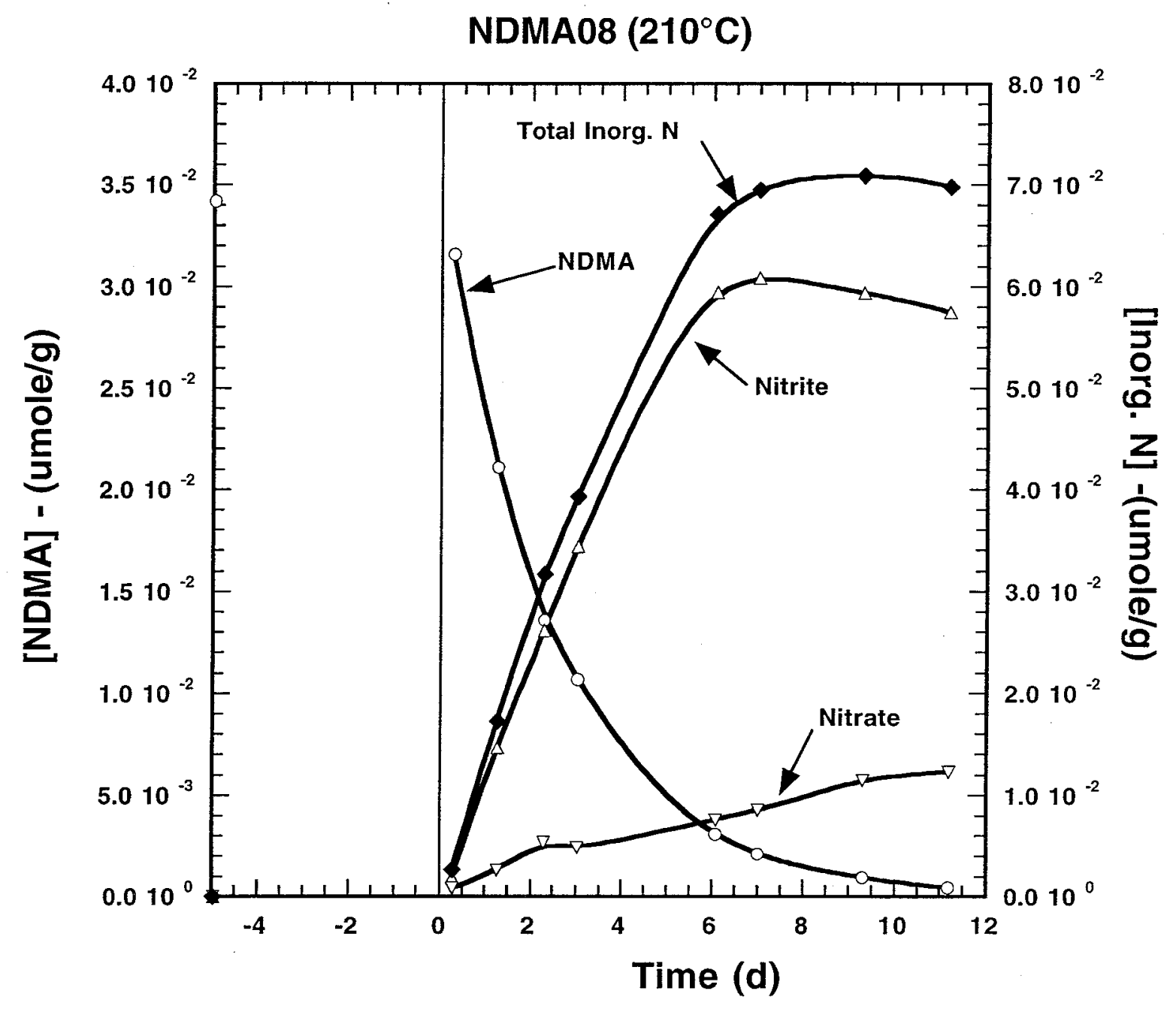

Figure 4. Concentration of NDMA, nitrite and nitrate vs. time for the phosphate-buffered $(\mathrm{pH}=7$ ) NDMA experiment run at $210^{\circ} \mathrm{C}$ and $11 \mathrm{ppm}$ dissolved $\mathrm{O}_{2}$. Vertical line at $\mathrm{t}=0$ represents the time when the reaction heater was turned on. 


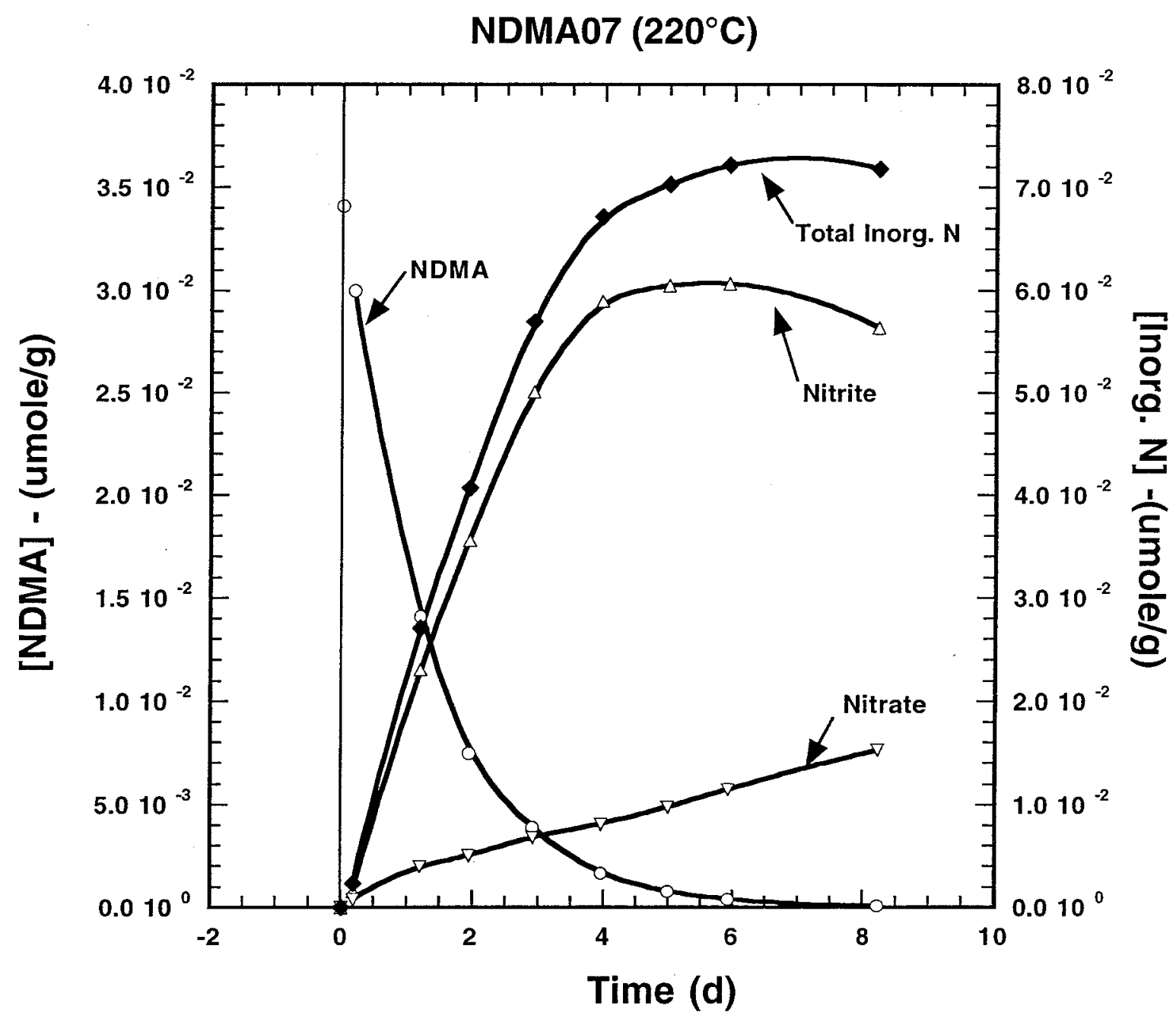

Figure 5. Concentration of NDMA, nitrite and nitrate vs. time for the phosphate-buffered $(\mathrm{pH}=7)$ NDMA experiment run at $220^{\circ} \mathrm{C}$ and $11 \mathrm{ppm}$ dissolved $\mathrm{O}_{2}$. Vertical line at $\mathrm{t}=0$ represents the time when the reaction heater was turned on. 


\section{DISCUSSION}

The primary objective of this study was to determine the feasibility of employing HPO as an in situ remediation method for groundwater contaminated by NDMA. These experiments have shown that NDMA is destroyed at the experimental reaction temperatures $\left(180^{\circ} \mathrm{C}-220^{\circ} \mathrm{C}\right)$ and a good nitrogen mass balance was achieved for the five experiments. Although the results indicate a near complete mass balance of nitrogen during the HPO treatment of NDMA, a similar carbon balance was not obtained. The lack of a carbon balance during the experiments indicated that inorganic carbon evolved from the oxidation of an organic contaminant. Although a portion of the dissolved oxygen was consumed by the organic contaminant there was still an excess of dissolved oxygen for oxidation of NDMA. The complete set of NDMA concentration data for the five experiments is plotted in Fig. 6.

\section{DETERMINATION OF HPO RATE CONSTANTS}

Fig. 7 is a plot of $\ln [\mathrm{NDMA}]$ vs. time for the five temperatures and the data for the five experiments were found to be linear over the entire duration of the experiment (i.e. no curvature detected during 5 or more half-lives) and therefore a first-order reaction. The filled symbols in Fig. 7 represent the data used to calculate the rate constants for each particular reaction temperature and the open symbols represent NDMA concentrations below the reporting limit of the GC-MS calibration curve. These data are included on the plot to demonstrate the linearity of the data. The integrated rate equation for a first-order reaction was used to determine the first-order rate constants. The first-order reaction rate constants for the loss of NDMA at the five reaction temperatures were calculated to be the following values : $\mathrm{k}_{1}=5.21 \times 10^{-7} \mathrm{~s}^{-1}$ at $180^{\circ} \mathrm{C}, \mathrm{k}_{1}=1.14 \mathrm{x}$ $10^{-6} \mathrm{~s}^{-1}$ at $190^{\circ} \mathrm{C}, \mathrm{k}_{1}=2.05 \times 10^{-6} \mathrm{~s}^{-1}$ at $200^{\circ} \mathrm{C}, \mathrm{k}_{1}=4.53 \times 10^{-6} \mathrm{~s}^{-1}$ at $210^{\circ} \mathrm{C}$ and $\mathrm{k}_{1}=8.81 \times 10^{-6} \mathrm{~s}^{-1}$ at $220^{\circ} \mathrm{C}$. The corresponding half-lives at these reaction temperatures are as follows : $\tau_{1 / 2}=15.5$ days at $180^{\circ} \mathrm{C}, \tau_{1 / 2}=7.3$ days at $190^{\circ} \mathrm{C}, \tau_{1 / 2}=3.6$ days at $200^{\circ} \mathrm{C}, \tau_{1 / 2}=1.8$ days at $210^{\circ} \mathrm{C}$ and $\tau_{1 / 2}$ $=0.9$ days at $220^{\circ} \mathrm{C}$. 


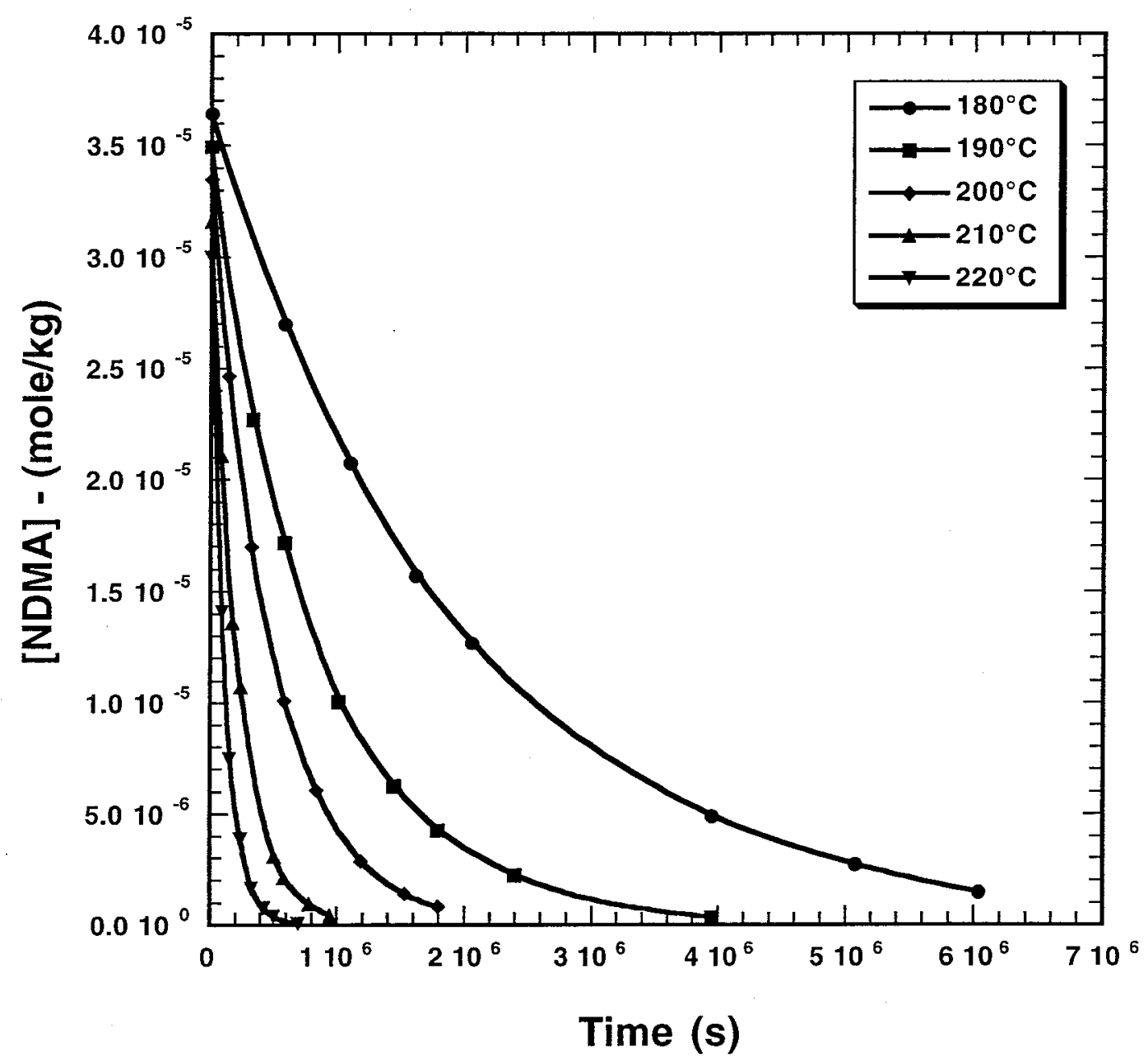

Figure 6. [NDMA] vs. time for the five NDMA experiments. 


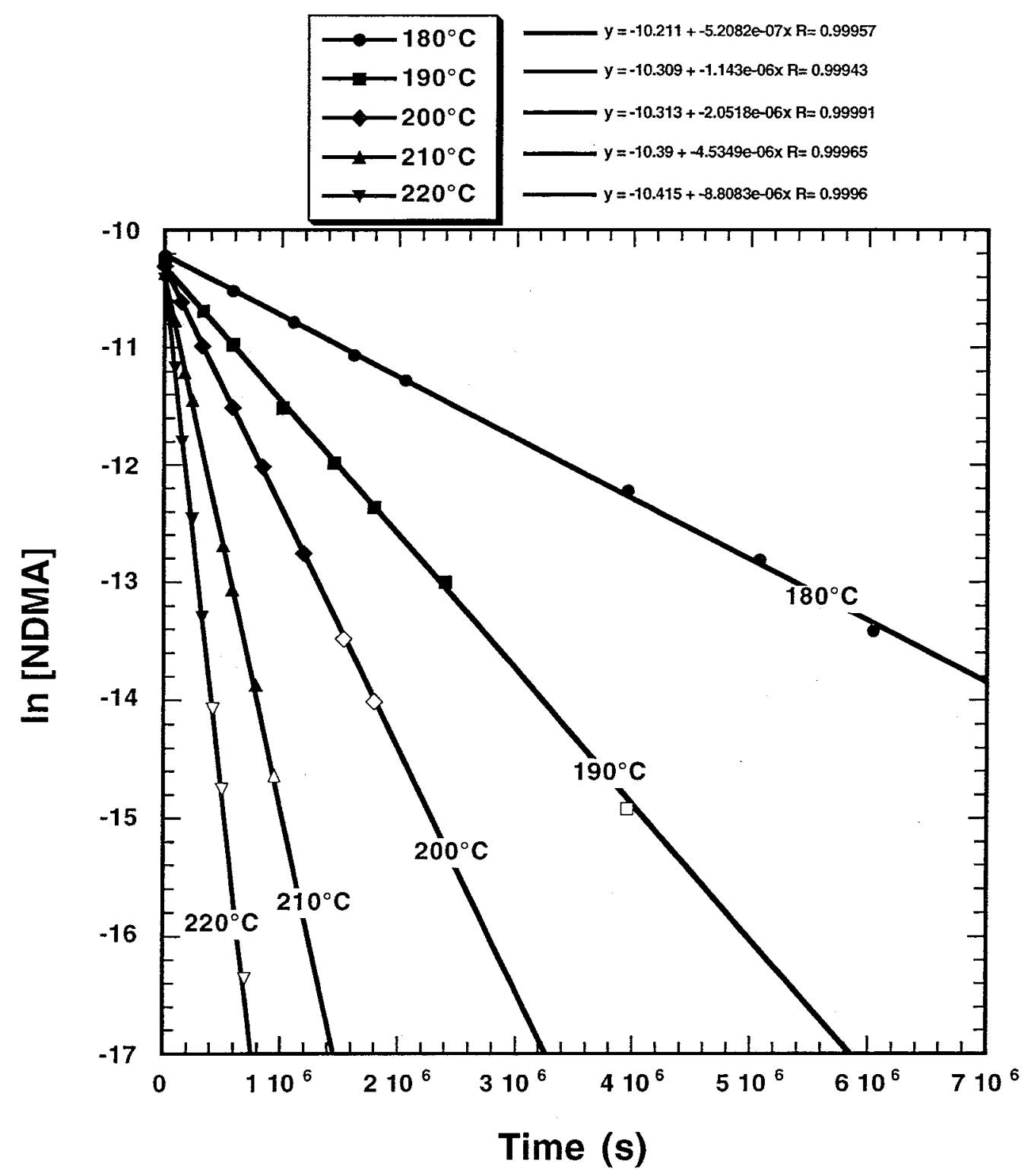

Figure 7. $\ln [\mathrm{NDMA}]$ vs. time for the five NDMA kinetics experiments. 


\section{THE ARRHENIUS EQUATION FOR THE HPO OF NDMA}

The temperature dependence of the first-order rate constants can be described using the Arrhenius equation; $\mathrm{R}$ is the gas constant, $\mathrm{E}_{\mathrm{act}}$ is the activation energy and $\mathrm{A}$ is the preexponential factor. Below is the linearized version of the Arrhenius equation :

$$
\ln \mathrm{k}_{1}=\ln \mathrm{A}+\left(\mathrm{E}_{\mathrm{acr}} / \mathrm{R}\right) 1 / \mathrm{T}
$$

Using the rate constants determined in the five HPO experiments, an Arrhenius plot was constructed and is shown in Fig. 8. Using the experimental results for the five temperatures, the linearized version of the equation is as follows :

$$
\ln \mathrm{k}_{1}=20.21-15716(1 / \mathrm{T})
$$

The activation energy for the reaction was calculated to be $130.7 \pm 3.5 \mathrm{~kJ} / \mathrm{mole}$. This relationship can be used to determine first-order rate constants at other temperatures. Extrapolating down to $125^{\circ} \mathrm{C}$, shown graphically in Fig. 9, a reasonable process temperature in the subsurface of WSTF,

results in a calculated first order rate constant of $4.30 \times 10^{-9} \mathrm{~s}^{-1}$ and an estimated half-life of 1870 days. 


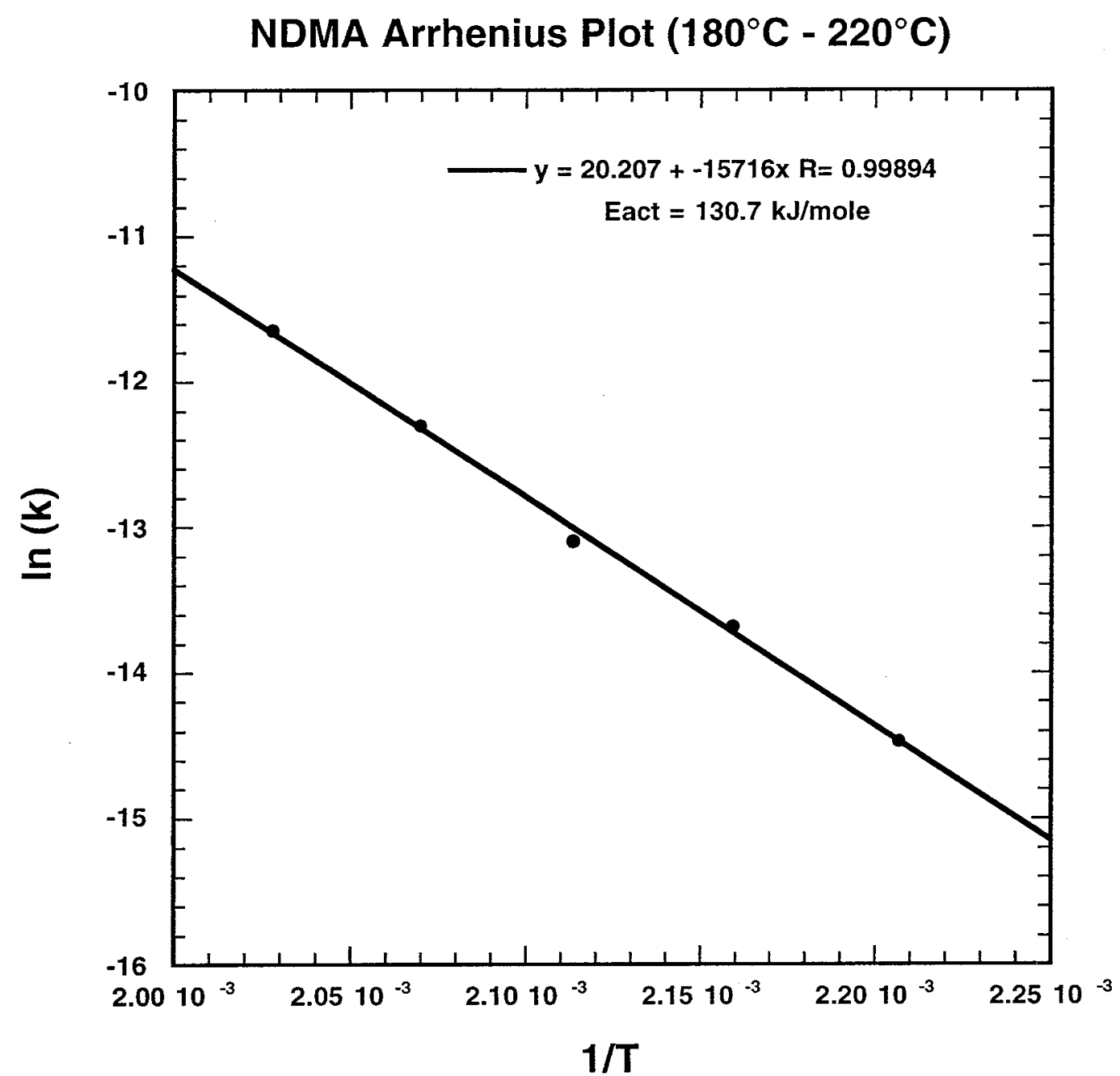

Figure 8. Arrhenius plot for the HPO experiments of NDMA from $180^{\circ} \mathrm{C}$ to $220^{\circ} \mathrm{C}$. The calculated value of $E_{\text {act }}$ is $130.7 \mathrm{~kJ} / \mathrm{mole}$. 


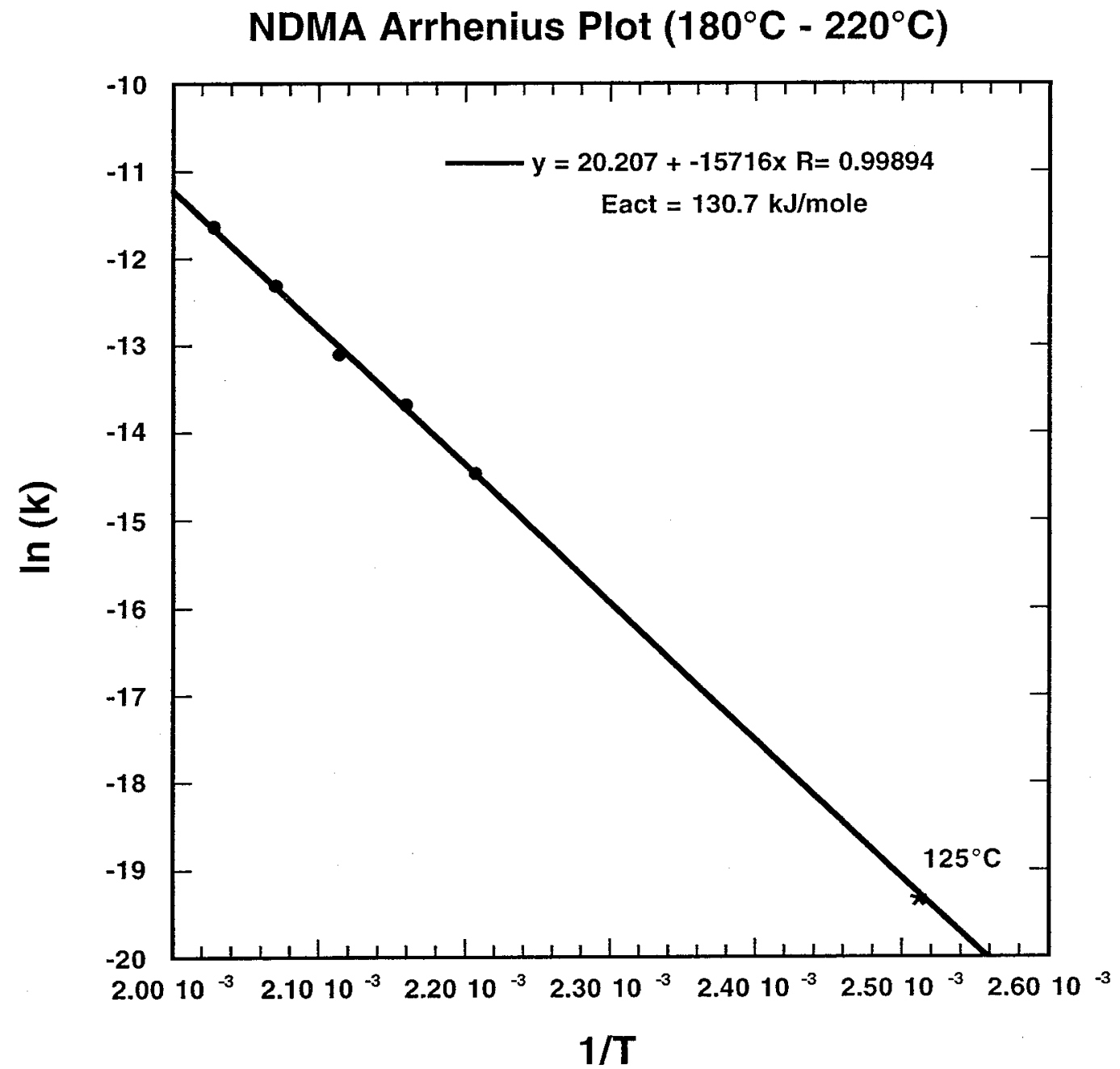

Figure 9. Extrapolation of the data to a groundwater process temperature of $125^{\circ} \mathrm{C}$. 


\section{SUMMARY}

This report describes the analytical procedures and presents the findings of the HPO experiments investigating the reactivity of $\mathrm{N}$-nitrosodimethylamine (NDMA) in laboratory scale hydrous pyrolysis / oxidation (HPO) experiments. The above set of experiments provides quantitative information regarding the HPO chemistry of NDMA. Oxidation rates determined at the five temperatures allowed an extrapolation of reaction rate constants to lower temperatures typical of field HPO temperatures.

Reaction temperatures for destruction of NDMA at WSTF would depend on the depth of the contaminated zone below the water table. East of the 400 area this ranges from approximately 0 to $100 \mathrm{ft}$. The boiling point at a $50 \mathrm{ft}$ depth below the water table is approximately $125^{\circ} \mathrm{C}$. This is the temperature that could be sustained, even though steam injection could achieve much higher

temperatures during the injection period (up to $170^{\circ} \mathrm{C}$ at $200 \mathrm{ft}$ depth). At the temperature of $125^{\circ} \mathrm{C}$ the destruction of NDMA has been determined to be extremely slow and demonstrates that HPO is not a viable remediation method for NDMA. 


\section{APPENDIX}

The Analytical Results from the Experiments on the HPO Chemistry of NDMA

In this Appendix the data table of the organic (GC-MS) and inorganic analyses are presented for the samples taken during experiments NDMA04, NDMA05, NDMA06, NDMA07 and NDMA08. 
Table 1. Results from the HPO experiments ranging trom $180^{\circ} \mathrm{C}$ to $220^{\circ} \mathrm{C}$.

\begin{tabular}{|c|c|c|c|}
\hline Sample ID & $\begin{array}{l}\text { Elapsed Time } \\
\text { (days) }\end{array}$ & $\begin{array}{c}\text { Adjusted Time } \\
\text { (days) }\end{array}$ & $\begin{array}{l}\text { Temperature } \\
\left({ }^{\circ} \mathrm{C}\right)\end{array}$ \\
\hline NDMA05-0 & -0.99 & & 22 \\
\hline NDMA05-0.3 & 0.34 & 0.00 & 180 \\
\hline NDMA05-7 & 7.05 & 6.71 & 180 \\
\hline NDMA05.13 & 13.02 & 12.68 & 180 \\
\hline NDMA05-19 & 19.01 & 18.67 & 180 \\
\hline NDMA05-24 & 24.06 & 23.72 & 180 \\
\hline NDMA05-45 & 45.02 & 44.68 & 180 \\
\hline NDMAO5-46 & 46.09 & 45.75 & 180 \\
\hline NDMA0 5.59 & 59.03 & 58.69 & 180 \\
\hline NDMA05-70 & 70.20 & 69.86 & 180 \\
\hline NDMA04-0 & -1.79 & & 22 \\
\hline NDMA $04=0.3$ & 0.34 & 0.00 & 190 \\
\hline NDMA04:4 & 4.13 & 3.79 & 190 \\
\hline NDMA04-7 & 7.05 & 6.71 & 190 \\
\hline NDMA04-12 & $\begin{array}{l}1.05 \\
12.02\end{array}$ & 11.68 & 190 \\
\hline NDMA04-17 & 17.08 & +6.74 & 190 \\
\hline NDMA04-21 & 21.01 & 20.68 & 190 \\
\hline NDMA04-28 & 28.00 & 27.67 & 190 \\
\hline NDMA04-45 & 45.01 & 44.68 & 190 \\
\hline NDMA04-46 & 46.09 & 45.75 & 190 \\
\hline NDMA06.0 & -4.01 & & $\begin{array}{l}21 \\
105\end{array}$ \\
\hline NDMA06-0.3 & 0.34 & 0.00 & \\
\hline $\begin{array}{l}\text { NDMA06-2 } \\
\text { NDMA06=4 }\end{array}$ & $\begin{array}{l}2.00 \\
4.03\end{array}$ & $\begin{array}{l}1.66 \\
3.69\end{array}$ & $\begin{array}{l}200 \\
200\end{array}$ \\
\hline NDMA06-7 & 7.05 & $\begin{array}{l}6.71 \\
6.71\end{array}$ & 200 \\
\hline NDMA06-10 & 10.02 & $\begin{array}{l}9.68 \\
9.68\end{array}$ & 200 \\
\hline NDMA06-14 & 14.07 & 13.73 & 200 \\
\hline NDMA06-18 & 18.01 & 17.67 & \\
\hline NDMA06-21 & 21.05 & 20.71 & 200 \\
\hline NDMA08.0 & .4 .98 & & 21 \\
\hline NDMAOB $=0.3$ & 0.28 & 0.00 & 210 \\
\hline NDMAOB-1.3 & 1.26 & 0.98 & 210 \\
\hline NDMAOB-2.3 & 2.28 & 1.99 & 210 \\
\hline NDMAO8-3 & $\begin{array}{l}2.20 \\
3.02\end{array}$ & 2.73 & 210 \\
\hline NDMAOB-6 & 6.07 & 5.79 & 210 \\
\hline NDMAOB-7 & 7.00 & 6.71 & 210 \\
\hline NDMAOB-9 & 9.30 & 9.01 & 210 \\
\hline NDMAOB-11 & 11.18 & 10.90 & 210 \\
\hline NDMA07-0 & 0.00 & & 20 \\
\hline NDMA07-0.2 & 0.18 & 0.00 & 220 \\
\hline NDMA $07-1.2$ & 1.20 & 1.02 & 220 \\
\hline & 1.94 & 1.76 & 220 \\
\hline NDMA07-3 & 2.91 & 2.73 & 220 \\
\hline NDMA07-4 & 3.96 & 3.78 & 220 \\
\hline NDMA07-5 & 4.99 & 4.81 & 220 \\
\hline NDMA07-6 & 5.92 & 5.74 & 220 \\
\hline NDMA 07-8 & 8.22 & 8.03 & 220 \\
\hline
\end{tabular}

\begin{tabular}{|c|c|c|c|c|c|c|}
\hline $\begin{array}{l}\text { Surr. Recovery } \\
(\%)\end{array}$ & $\begin{array}{l}\text { [NDMA] } \\
\text { (Umol/g) }\end{array}$ & $\begin{array}{c}\text { Nitrite } \\
\text { (umole/g) }\end{array}$ & $\begin{array}{c}\text { Nitrate } \\
\text { (umole/g) }\end{array}$ & $\begin{array}{l}\text { Total inorg. N } \\
\text { (umole/g) }\end{array}$ & $\begin{array}{l}\text { Total } \mathrm{CO} 2 \\
\text { (umol/g) }\end{array}$ & $\begin{array}{l}\text { Dissolved } 02 \\
\text { (umol/g) }\end{array}$ \\
\hline 103.6 & $3.81 \mathrm{E}-02$ & $0.00 \mathrm{E}+00$ & $0.00 \mathrm{E}+00$ & $0.00 \mathrm{E}+00$ & $4.62 \mathrm{E}-02$ & $3.06 \mathrm{E}-01$ \\
\hline 99.6 & $3.64 \mathrm{E}-02$ & $0.00 \mathrm{E}+00$ & $1.30 E-03$ & $1.30 \mathrm{E}-03$ & $4.38 \mathrm{E}-02$ & n.a. \\
\hline 99.8 & $2.70 \mathrm{E}-02$ & $1.24 \mathrm{E}-02$ & $2.04 \mathrm{E}-03$ & $1.44 \mathrm{E}-02$ & $6.70 \mathrm{E}-02$ & n.a. \\
\hline 100.0 & $2.07 \mathrm{E}-02$ & $2.16 \mathrm{E}-02$ & $3.30 \mathrm{E}-03$ & $2.49 \mathrm{E}-02$ & $8.01 \mathrm{E}-02$ & ก.a. \\
\hline 100.2 & 1.57E-02 & $3.02 E-02$ & $4.05 \mathrm{E}-03$ & 3.43E-02 & $9.94 E-02$ & n.a. \\
\hline 100.2 & $1.27 \mathrm{E}-02$ & $3.60 \mathrm{E}-02$ & $4.88 \mathrm{E}-03$ & $4.09 \mathrm{E}-02$ & $9.98 \mathrm{E}-02$ & ก.a. \\
\hline n.a. & n.a. & $5.04 \mathrm{E}-02$ & $8,15 \mathrm{E}-03$ & $5.86 \mathrm{E}-02$ & & n.a. \\
\hline 99.6 & $4.91 \mathrm{E} \cdot 03$ & $5.07 \mathrm{E}-02$ & $7.97 \mathrm{E}-03$ & $5.86 \mathrm{E}-02$ & 1.32E-01 & n.a. \\
\hline 92.2 & $2.73 \mathrm{E}-03$ & $5.10 \mathrm{E}-02$ & $9.94 \mathrm{E}-03$ & $6.10 \mathrm{E} \cdot 02$ & $1,25 \mathrm{E}-01$ & $1.39 \mathrm{E}-01$ \\
\hline 95.4 & $1.49 \mathrm{E}-03$ & $5.42 \mathrm{E}-02$ & $1.14 \mathrm{E}-02$ & $6.56 \mathrm{E} \cdot 02$ & $1.28 \mathrm{E}-01$ & 1. $33 \mathrm{E}-01$ \\
\hline 102.6 & 3.62E-02 & $0.00 E+00$ & $0,00 E+00$ & $0.00 E+00$ & $4.16 \mathrm{E}-02$ & $3.36 \mathrm{E} \cdot 01$ \\
\hline 98.8 & 3.50E-02 & $0.00 E+00$ & $0.00 E+00$ & $0.00 E+00$ & $4.24 \mathrm{E}-02$ & n.a. \\
\hline 100.8 & 2.27E-02 & 1.53E-02 & $2.48 \mathrm{E}-03$ & $1.78 \mathrm{E} \cdot 02$ & $7.87 \mathrm{E}-02$ & n.a. \\
\hline 103.4 & 1.72E-02 & $2.50 \mathrm{E}=02$ & $3.56 \mathrm{E}-03$ & $2.86 \mathrm{E}-02$ & $8.54 \mathrm{E}-02$ & n.a. \\
\hline 98.4 & $1.01 \mathrm{E}-02$ & $3.96 \mathrm{E}-02$ & $4.94 \mathrm{E}-03$ & $4.45 \mathrm{E}-02$ & 1.08E-01 & n.a. \\
\hline 99.0 & $6.26 \mathrm{E}-03$ & 4.81E-02 & $6.51 \mathrm{E}-03$ & $5.46 \mathrm{E}-02$ & 1.19E-01 & n.a. \\
\hline 103.6 & $4.28 \mathrm{E}-03$ & $5.24 \mathrm{E}-02$ & $7.18 \mathrm{E}-03$ & $5.95 \mathrm{E}-02$ & 1.23E-01 & n.a. \\
\hline 102.8 & $2.26 \mathrm{E}-03$ & $5.60 \mathrm{E}-02$ & 1.07E-02 & $6.67 \mathrm{E}-02$ & $1.45 \mathrm{E}-01$ & n.a. \\
\hline n.a. & n.a. & $4.86 \mathrm{E}-02$ & $1.81 \mathrm{E}-02$ & $6.67 \mathrm{E}-02$ & 1.36E-01 & n.a. \\
\hline 98.6 & 3.32E-04 & $4.79 \mathrm{E} \cdot 02$ & $1.87 \mathrm{E}-02$ & $6.66 \mathrm{E}-02$ & $1.32 \mathrm{E}-01$ & $1.85 \mathrm{E}-01$ \\
\hline 95.8 & 3.51E-02 & $0.00 E+00$ & $0.00 E+00$ & $0.00 E+00$ & $4.14 \mathrm{E}-02$ & 3.37E-01 \\
\hline 96.4 & 3.35E-02 & $1.34 \mathrm{E}-03$ & $1.52 E-03$ & $2.86 \mathrm{E}-03$ & $5.16 \mathrm{E}-02$ & n.a.. \\
\hline 101.6 & $2.47 \mathrm{E}-02$ & $1.26 \mathrm{E}-02$ & $3.26 \mathrm{E}-03$ & $1.59 \mathrm{E}-02$ & 7.56E-02 & n.a. \\
\hline 102.0 & 1.70E-02 & $2.54 \mathrm{E}-02$ & $4.23 \mathrm{E}-03$ & $2.96 \mathrm{E}-02$ & $1.01 \mathrm{E}-01$ & ก.a. \\
\hline 103.0 & $1.01 \mathrm{E}-02$ & $3.97 \mathrm{E}-02$ & $5.44 \mathrm{E}-03$ & $4.52 \mathrm{E}-02$ & $1.12 E-01$ & n.a. \\
\hline 104.4 & $6.08 \mathrm{E}-03$ & $4.65 \mathrm{E} \cdot 02$ & $7.03 \mathrm{E}-03$ & $5.36 \mathrm{E}-02$ & $1,21 \mathrm{E}-01$ & n.a. \\
\hline 101.6 & $2.89 \mathrm{E}-03$ & $5.41 \mathrm{E}-02$ & $9.72 E-03$ & $6.38 \mathrm{E}-02$ & $1.33 E-01$ & n.a. \\
\hline 106.4 & $1,40 \mathrm{E}-03$ & $5.50 \mathrm{E}-02$ & $1.12 \mathrm{E}-02$ & $6.62 \mathrm{E}-02$ & & n.a. \\
\hline 100.0 & $8.22 \mathrm{E}-04$ & $5.60 \mathrm{E}-02$ & $1.28 \mathrm{E}-02$ & $6.87 \mathrm{E}-02$ & $1.46 \mathrm{E}-01$ & $1.24 \mathrm{E}-01$ \\
\hline $\begin{array}{c}95.4 \\
102.0\end{array}$ & $\begin{array}{l}3.42 \mathrm{E}-02 \\
3.16 \mathrm{E}-02\end{array}$ & $\begin{array}{l}0.00 E+00 \\
1.89 E-03\end{array}$ & $\begin{array}{l}0.00 \mathrm{E}+00 \\
8.48 \mathrm{E}-04\end{array}$ & $\begin{array}{l}0.00 \mathrm{E}+00 \\
2.74 \mathrm{E}-03\end{array}$ & $\begin{array}{l}3.39 \mathrm{E}-02 \\
9.38 \mathrm{E} \cdot 02\end{array}$ & $\begin{array}{l}3.50 E \cdot 01 \\
\text { n.a. }\end{array}$ \\
\hline 104.4 & $2.11 \mathrm{E}-02$ & 1.47E-02 & $2.64 \mathrm{E}-03$ & $1.73 \mathrm{E} \cdot 02$ & $1.27 \mathrm{E}-01$ & n.a. \\
\hline 101.0 & $1,36 \mathrm{E} \cdot 02$ & $2.62 \mathrm{E}-02$ & $5.43 \mathrm{E}-03$ & $3.17 \mathrm{E}-02$ & $1.39 \mathrm{E}-01$ & n.a. \\
\hline 105.4 & 1.07E-02 & $3.44 \mathrm{E}-02$ & $4.91 \mathrm{E}-03$ & $\begin{array}{l}3.93 E-02 \\
.71 E\end{array}$ & 1.61E-01 & ก.a. \\
\hline 95.0 & $3.09 E-03$ & $5.95 E-02$ & $7.64 \mathrm{E}-03$ & $6.71 E-02$ & n.a. & n.a. \\
\hline 92.4 & $2.13 \mathrm{E}-03$ & $6.09 \mathrm{E}-02$ & $8.58 \mathrm{E}-03$ & $6.95 \mathrm{E}-02$ & n.a. & na. \\
\hline 97.2 & $9.46 \mathrm{E}-04$ & $5.94 \mathrm{E}-02$ & $1.15 \mathrm{E}-02$ & $7.09 \mathrm{E}-02$ & $1.93 E-01$ & 1.18E-01 \\
\hline 90.8 & $4.41 \mathrm{E} \cdot 04$ & $5.75 E-02$ & $1.23 \mathrm{E} \cdot 02$ & $6.98 \mathrm{E}-02$ & $1.97 \mathrm{E}-01$ & n.a. \\
\hline 94.2 & $3.41 \mathrm{E}-02$ & $0.00 E+00$ & $0.00 E+00$ & $0.00 E+00$ & $6.74 \mathrm{E}-02$ & $3.39 \mathrm{E}-01$ \\
\hline 93.8 & $3.00 \mathrm{E}-02$ & $1.61 \mathrm{E}-03$ & $7.65 \mathrm{E} \cdot 04$ & 2.37E-03 & 1.27E-01 & n.a. \\
\hline 94.8 & $1.41 \mathrm{E}-02$ & $2.31 \mathrm{E}-02$ & $4.01 E-03$ & $2.71 \mathrm{E}-02$ & $1.21 \mathrm{E}-01$ & n.a. \\
\hline 97.8 & $7.51 \mathrm{E}-03$ & $3.56 \mathrm{E}-02$ & $5.04 \mathrm{E}-03$ & $4.07 \mathrm{E}-02$ & 1.55E-01 & n.a. \\
\hline 99.4 & $3.89 \mathrm{E}-03$ & $5.01 \mathrm{E}-02$ & $6.88 \mathrm{E}-03$ & $5.70 E-02$ & $1.48 \mathrm{E}-01$ & n.a. \\
\hline 90.4 & $1.68 \mathrm{E}-03$ & $5.90 \mathrm{E}-02$ & $8.15 \mathrm{E}-03$ & $6.72 \mathrm{E}-02$ & n.a. & n.a. \\
\hline 92.0 & 7.74E-04 & $6.05 \mathrm{E}-02$ & $9.80 \mathrm{E}-03$ & $7.03 \mathrm{E}-02$ & n.a. & ก.a. \\
\hline 99.8 & $3.93 E-04$ & $6.07 E-02$ & 1. $15 \mathrm{E} \cdot 02$ & 7.22E-02 & n.a. & n.a. \\
\hline 99.8 & $7,88 \mathrm{E}-05$ & $5.64 \mathrm{E}-02$ & $1.53 \mathrm{E}-02$ & $7.18 \mathrm{E}-02$ & $1.72 E-01$ & $1.18 \mathrm{E} \cdot 01$ \\
\hline
\end{tabular}

n.a. $=$ not analyzed

- = data not reported due to sample loss 